\title{
STRATEGI IMAGE REPAIR PT HM SAMPOERNA TBK PADA PERISTIWA 'KARYAWAN PABRIK SURABAYA POSITIF COVID-19'
}

\author{
M. Ramzy Hasibuan \\ Magister Ilmu Komunikasi, Departemen Ilmu Komunikasi, Universitas Indonesia, \\ Kota Depok, Jawa Barat, Indonesia \\ Email: hasibuanramzy@gmail.com \\ Irwansyah \\ Staf Pengajar Ilmu Komunikasi FISIP UI, Universitas Indonesia, \\ Kota Depok, Jawa Barat, Indonesia \\ Email:dr.irwansyah.ma@gmail.com
}

\section{Article Info \\ Article History \\ Received 30 May 2020 \\ Revised 18 Oct 2020 \\ Accepted 30 Oct 2020}

\begin{abstract}
The use of Image Repair Theory for companies during crisis communication is an interesting study. It is also applied when several PT HM Sampoerna Tbk factory employees are known to have died due to suffering from COVID-19. This event affected the company's image, especially the negative sentiment on the quality of the products produced due to employees affected by COVID-19. This study analyzes the image repair strategy used by PT HM Sampoerna Tbk through press releases published on the company's official website. The research objective is to analyze message options for organizations to use in times of crisis. The study uses a qualitative content analysis method by analyzing text written in press releases, then putting it into categories that have been determined in the image repair strategy. The results showed PT HM Sampoerna Tbk's inconsistency in using the Reducing Offensiveness strategy, which is often used in types of accident and/or challenge crises, including product damage situations. Excessive use of Reducing Offensiveness must be an organization's concern when conducting crisis communication, especially when the audience has a critical view of the organization. Reducing Offensiveness can be more optimally used by neutral third parties than the organization itself; however, the research results show that PT HM Sampoerna Tbk carries out all strategy delivery.
\end{abstract}

Keywords: image repair theory, crisis communication, image repair strategy, covid-19, sampoerna 


\begin{abstract}
Abstrak: Penggunaan Image Repair Theory bagi perusahaan saat melakukan komunikasi krisis menjadi kajian yang menarik. Termasuk juga ketika beberapa karyawan pabrik PT HM Sampoerna Tbk, diketahui meninggal dunia akibat menderita COVID-19. Peristiwa ini memengaruhi citra perusahaan, terlebih adanya sentiment negatif atas kualitas produk yang dihasilkan karena adanya karyawan yang terkena COVID-19. Penelitian ini menganalisis strategi image repair yang digunakan PT HM Sampoerna Tbk lewat rilis pers yang dipublikasikan lewat laman resmi perusahaan. Tujuan penelitian adalah memberikan analisis opsi pesan bagi organisasi untuk dapat digunakan pada saat krisis. Penelitian menggunakan metode analisis isi kualitatif dengan menganalisis teks yang tertulis dalam rilis pers, ke dalam kategorikategori yang telah ditentukan dalam strategi image repair. Hasil penelitian menunjukkan ketidakkonsistenan PT HM Sampoerna Tbk dalam penggunaan strategi Reducing Offensiveness, yang memang sering digunakan dalam jenis krisis kecelakaan dan/atau tantangan, termasuk situasi kerusakan produk. Penggunaan Reducing Offensiveness secara berlebihan harus menjadi perhatian organisasi saat melakukan komunikasi krisis, terutama ketika audience kritis terhadap organisasi. Reducing Offensiveness dapat lebih optimal digunakan oleh pihak ketiga yang netral daripada organisasi itu sendiri, namun dalam hal ini seluruh penyampaian strategi dilakukan pihak PT HM Sampoerna Tbk sendiri.
\end{abstract}

Kata kunci: image repair theory, covid-19, komunikasi krisis, image repair strategy, sampoerna

\section{PENDAHULUAN}

Sangat penting bagi pelaku industri
untuk mendapatkan kepercayaan konsumen. Menurut Reissová et al., (2018), minat konsumen dapat turun begitu ada keraguan tentang kualitas produk yang dijual. Jika keraguan semacam itu dihubungkan dengan dampak nyata pada kehidupan, hal itu dapat berdampak negatif pada operasi bisnis. Ketidakseimbangan ini menghasilkan situasi krisis yang harus dihadapi bisnis tanpa bisa ditunda.

Nijkrake et al., (2015) mendefinisikan krisis sebagai "peristiwa mendadak dan tak terduga yang mengancam akan mengganggu operasi organisasi dan menimbulkan ancaman finansial dan reputasi." Karena krisis dicirikan oleh tingkat ketidakpastian yang tinggi, tanpa penyebaran informasi yang tepat waktu, ada kemungkinan bahwa rumor akan mendominasi wacana krisis, meningkatkan ketidakpastian, dan memperburuk situasi.

Bisnis yang dikelola dengan baik harus mengantisipasi semua risiko dalam manajemen risikonya. Oleh karena itu, organisasi bisnis perlu menentukan cara berkomunikasi dengan berbagai pemangku kepentingan untuk tetap menjaga hubungan. Apalagi komunikasi perusahaan selama dan setelah krisis diasumsikan adalah salah satu faktor terpenting dalam menentukan jangka panjang efek dari suatu krisis.

Pada 2019, misalnya, wilayah Jabodetabek serta sebagian wilayah Jawa Barat dan Jawa Tengah mengalami mati listrik berjam-jam. Kasus ini menarik 
perhatian publik, hingga presiden Jokowi Widodo pun meminta penjelasan langsung dari direksi PLN (Ramadhan, 2019). Dalam kasus ini, Riza (2019) melihat bahwa respons komunikasi krisis yang dilakukan belum mencerminkan skema komunikasi krisis yang efektif. Publik justru dibombardir viralnya informasi "liar tapi benar" menyangkut dampak listrik yang padam.

Manajer komunikasi dari sebuah perusahaan mungkin berusaha membingkai krisis sedemikian rupa sehingga dapat meminimalkan kerusakan reputasi pada organisasi yang dinaungi. Misalnya, hanya menyoroti informasi tertentu sebagai subjek komunikasi, sehingga informasi ini menjadi hal yang penting (Entman, 1993). Cara pesan dibingkai membentuk cara orang mendefinisikan masalah, penyebab masalah, atribusi tanggung jawab, dan solusi untuk masalah, sehingga pada akhirnya memengaruhi persepsi publik. Oleh karena itu, sangat penting melakukan komunikasi yang efektif selama krisis lewat pembingkaian, agar publik dapat memahami situasi yang ada. Komunikasi efektif saat krisis harus mampu membuat pemangku kepentingan dapat menafsirkan krisis dengan baik. Komunikasi ini tentu dapat dilakukan lewat media berita, yang tentu saja diproduksi oleh organisasi media yang ingin menyoroti keadaan dan dapat memberikan interpretasi tertentu. Bingkai ini kemudian didistribusikan ke berbagai saluran media untuk menjangkau khalayak luas (Gilpin, 2008).

Pada 30 April 2020, Kompas memberitakan salah satu kompleks pabrik PT HM Sampoerna Tbk di kawasan Rungkut, Surabaya, Jawa Timur, ditutup setelah dua orang karyawan pabrik tersebut meninggal dunia akibat terinfeksi virus Corona. Sembilan pegawai ditetapkan sebagai Pasien Dalam Pengawasan (PDP) dan kini tengah menjalani perawatan. Terdapat 500 karyawan lain di kompleks pabrik tersebut yang berpotensi tertular virus (Belarminus, 2020).

Berbagai informasi terkait hal ini kemudian tersebar di media sosial. Liputan6.com, misalnya, memeriksa fakta atas kabar jutaan rokok Sampoerna terpapar virus corona yang beredar di masyarakat karena ada pekerja di pabriknya yang positif terinfeksi COVID19. Kabar tersebut diunggah akun Facebook Hansen Latuconsina, pada 30 April 2020. Kalimat awal unggahan berbunyi: "Jutaan Produksi Rokok Yang Terpapar Covid-19 Beredar Luas Di Masyarakat” (Wicaksono, 2020).

Peristiwa ini pun merembet hingga penundaan pelaksanaan paparan publik tahunan (public expose) PT HM Sampoerna Tbk yang awalnya direncanakan pada 18 Mei 2020. Seperti diberitakan oleh Bisnis.com, dikutip dari surat keterangan yang ditandatangani oleh Sekretaris Perusahaan Bambang Priambodo di laman keterbukaan informasi Bursa Efek Indonesia (BEI), rencana pelaksanaan paparan publik yang seharusnya dilaksanakan pada bulan ini ditunda (Situmorang, 2020).

Peristiwa ini juga memengaruhi harga saham emiten rokok PT HM Sampoerna Tbk. Dikutip dari cnbcindonesia.com, pada perdagangan hari Senin, 5 Mei 2020 pada pukul 10:00 WIB melemah 60 poin atau $3,76 \%$ menjadi $\mathrm{Rp}$ 1.535/saham setelah ada karyawan yang meninggal lantaran positif Covid-19 (Haryanto, 2020).

PT Hanjaya Mandala Sampoerna Tbk adalah salah satu pelaku industri tembakau di Indonesia yang telah berdiri sejak tahun 1913. PT HM Sampoerna Tbk mengklaim menjadi pemimpin pasar rokok Indonesia dengan pangsa pasar sebesar $32,2 \%$ pada tahun 2019. Secara reputasi, 
berbagai prestasi telah diraih perusahaan ini. Salah satu penghargaan terakhir adalah ASEAN Corporate Governance Awards 2018 kategori 2 Most Improved Public Listed Companies oleh ASEAN Capital Markets Forum (ACMF). Prestasi ini menurut Liputan6 turut meningkatkan reputasi perusahaan dalam komunitas ekonomi ASEAN, terlebih ACMF merupakan forum yang beranggotakan para regulator pasar modal ASEAN, termasuk Otoritas Jasa Keuangan (OJK).

Dengan posisi sebagai pemimpin pasar dan mempunyai reputasi yang baik, tersiarnya kasus positif karyawan Sampoerna di Surabaya tentu dapat menciptakan krisis. Selama krisis, citra dan reputasi organisasi sering terancam (Benoit dan Pang, 2008). Ini adalah saatsaat ketika organisasi diminta segera melakukan respons. Hal ini juga sesuai dengan Coombs (2007) bahwa komunikasi diperlukan saat dapat mengancam akan mengganggu operasi perusahaan dan menimbulkan ancaman finansial dan reputasi.

Pihak manajemen PT HM Sampoerna Tbk sendiri berupaya melakukan upaya komunikasi krisis dengan menyiarkan tiga rilis pers yang isinya dapat diakses publik lewat website resmi https://www.pmi.com/sampoerna/id. Dalam komunikasi krisis, menurut Friedman (2001), manajemen memang harus menawarkan informasi untuk mengurangi kemungkinan spekulasi dan informasi yang tidak akurat yang dilaporkan oleh media kepada publik.

Berdasarkan penjelasan di atas, penulis akan menganalisis strategi perbaikan citra yang dilakukan PT HM Sampoerna Tbk dengan menggunakan teori Image Repair oleh Benoit. Tujuan penelitian adalah memberikan analisis opsi pesan bagi organisasi untuk dapat digunakan pada saat krisis.
Image Repair dan Image Restoration adalah dua teori yang sama. Namun, William Benoit sebagai pencetus teori ini belakangan cenderung memakai kata "Repair". Menurut Benoit (2000), ini karena "Restoration" menyiratkan bahwa citra seseorang telah dikembalikan ke keadaan semula. Padahal, menurutnya, terkadang kita harus puas dengan perbaikan (repair).

Image Repair Theory muncul berdasarkan pada premis bahwa manusia terlibat dalam pola perilaku komunikatif berulang yang dirancang untuk mengurangi, memperbaiki, atau menghindari kerusakan reputasi mereka (atau wajah atau gambar) dari kesalahan yang dirasakan (W. L Benoit, 1995). Menurut Brinson dan Benoit (1999, p. 486), ketika orang, kelompok, dan organisasi dituduh melakukan perilaku yang tidak menyenangkan, reputasi dapat rusak. Retorika dari Image Repair berupaya memperbaiki dugaan atau dugaan kesalahan tersebut.

Image Repair Theory memberikan pilihan konseptual bagi para pelaku komunikasi yang perlu melakukan permintaan maaf atau membela diri. Teori ini mengasumsikan bahwa komunikasi digerakkan oleh sebuah tujuan dan reputasi milik seseorang sangat berharga sehingga mereka yang dituduh melakukan kesalahan, termotivasi untuk memperbaiki reputasi mereka yang rusak (W. L Benoit, 1995).

Sejak Benoit merumuskan teori ini, sebagian besar strategi Image Repair telah dipelajari dalam konteks reaksi organisasi terhadap krisis. Tak hanya organisasi, menurut Pang et al., (2012), sejak buku pertama tentang image repair diterbitkan pada 1995, Benoit dan rekan-rekannya telah menerapkan teori tersebut untuk menganalisis cara organisasi, individuindividu terkemuka, negara dan 
pemerintah dalam memperbaiki citra mereka. Studi-studi ini telah diterbitkan dalam jurnal komunikasi serta jurnal nonkomunikasi, dan digambarkan sebagai "paradigma dominan untuk memeriksa komunikasi perusahaan di saat krisis".

Menurut Benoit, terdapat 5 macam jenis pesan dalam perbaikan reputasi. Pertama, denial (Penyangkalan). Menurut Image Repair Theory, ada dua jenis penyangkalan, yakni penyangkalan sederhana dan shifting the blame. Penyangkalan sederhana menyatakan bahwa peristiwa atau tindakan berbahaya itu tidak terjadi, atau tidak tersangkut dalam peristiwa atau melakukan tindakan itu, atau bahwa peristiwa atau tindakan itu tidak membahayakan. Sementara shifting the blame, berusaha mengidentifikasi biang keladi permasalahan, dan melemparkan tanggung jawab atas peristiwa atau tindakan ofensif tersebut di pihak lain. Kedua, evading responsibility (menghindari tanggung jawab). Strategi ini dapat digunakan oleh "mereka yang tidak dapat menyangkal melakukan tindakan atau terjadinya peristiwa tersebut." (W. L Benoit, 1995). Ada empat strategi dalam kaitan ini, yakni provocation (provokasi), defeasibility (kemustahilan), accident (kecelakaan), dan good intentions (niat baik), yang bertujuan mengurangi kadar kesalahan yang dituduhkan kepada tertuduh. Ketiga, Reducing Offensiveness (mengurangi serangan). Strategi umum ketiga adalah upaya untuk "mengurangi tingkat perasaan sakit yang dialami oleh khalayak" (W. L Benoit, 1995). Strategi ini memiliki enam subkategori, yakni bolstering (memperkuat), minimization (minimalisasi), differentiation (membuat perbedaan),

transcendence (transendensi), attacking one's accusers (menyerang penuduh), dan compensation (kompensasi). Keempat, corrective action (tindakan perbaikan). Strategi ini dapat dilakukan dengan dua cara, tertuduh dapat mencoba memulihkan situasi dengan melakukan tindakan tertentu, atau berjanji untuk berperilaku berbeda di masa depan. Kelima, mortification (mengakui kesalahan). Istilah yang dipopulerkan oleh Burke (1970) ini menjelaskan strategi terakhir dan merujuk pada ucapan yang digunakan untuk menerima tanggung jawab atas tindakan ofensif/peristiwa yang terjadi, meminta maaf, dan meminta pengampunan. Pernyataan penyesalan juga termasuk dalam kategori ini.

Kendati penggunaan teori ini telah banyak dijadikan pisau analisis di banyak penelitian, tapi Holtzhausen dan Roberts mengkritisi kebanyakan kasus strategi Image Repair adalah penelitian dalam konteks analisis kasus retoris deskriptif dengan peneliti selalu berdebat atau menentang keberhasilan strategi tertentu.

Pang (2006) mengemukakan bahwa beberapa strategi seperti denial dan evading responsibility lebih bersifat advokasi, sedangkan yang lain seperti mortification lebih bersifat akomodatif. Namun, ada pula strategi yang berada di "tengah" antara advokasi dan akomodasi, seperti strategi reducing offensiveness.

Strategi yang bersifat advokasi berusaha untuk melindungi organisasi, sementara strategi yang bersifat akomodatif berusaha untuk mengatasi masalah para pemangku kepentingan. Pang menilai masuk akal bagi organisasi untuk mengadopsi strategi atau tindakan campuran dalam menanggapi pemangku kepentingan mereka. Benoit dan Hirson (2001) berpendapat bahwa strategi image repair harus "sesuai secara kolektif maupun individual".

Image Repair Theory menyatakan bahwa kredibilitas organisasi bergantung cukup besar pada citranya. Ancaman terhadap citra ini sering membutuhkan upaya besar untuk memperbaikinya (Benoit \& Brinson, 1999). Image Repair 
Theory memberikan opsi pesan bagi organisasi untuk digunakan pada saat krisis. Menurut Pang et al., (2012), sejak buku pertama tentang perbaikan gambar diterbitkan pada 1995, Benoit dan rekanrekannya telah menerapkan teori ini untuk menganalisis bagaimana organisasi memperbaiki citra mereka di antara sejumlah besar studi lain (lihat Benoit \& Brinson, 1994; Benoit \& Czerwinski, 1997; Benoit \& Pang 2008; Cowden \& Sellnow, 2002). Studi Image Repair telah diterbitkan dalam jurnal komunikasi serta jurnal non-komunikasi dan telah digambarkan sebagai "paradigma dominan untuk memeriksa komunikasi perusahaan di saat krisis" (Dardis \& Haigh, 2009) .

Studi tentang Image Repair Theory saat ini menurut Pang et al., (2012) deskriptif dan retrospektif, singkat pada prediksi dan kesimpulan (Coombs \& Schmidt, 2000; Dardis \& Haigh, 2009). Image Repair merupakan studi mempelajari teks, tetapi pada saat krisis, konteks sama pentingnya, seperti reputasi sebelumnya (Coombs, 2008; Lyon \& Cameron, 2004); hubungan organisasipemangku kepentingan (Coombs, 2008; Haigh \& Brubaker, 2010); tipe krisis (Coombs, 2008); kredibilitas sumber (Haigh \& Brubaker, 2010); situasi krisis dan tahap krisis (Benoit, 1997), saluran komunikasi (Caldiero, Taylor, \& Ungureanu, 2009) dan waktu respons (Pang et al., 2012). Namun, dengan segala keterbatasannya, efektivitas tanggapan retoris tidak dapat diremehkan. Misalnya, respons permintaan maaf telah ditemukan sebagai strategi krisis yang paling efektif (Kim, Avergy, \& Lariscy, 2009). Choi dan Lin (2009) berpendapat simpati dan kompensasi adalah respons yang sama efektifnya. Permintaan maaf disertai dengan pernyataan afirmatif seperti menerima tanggung jawab (Pace, Fediuk, \& Botero, 2010) dan tindakan korektif (Blaney, Benoit, \& Brazeal, 2002) membantu organisasi menebus pelanggaran yang terjadi.

\section{METODE}

Penelitian ini menggunakan pendekatan kualitatif dengan peneliti sebagai instrumen primer dalam pengumpulan, pengolahan serta dalam menganalisis data. Metode yang digunakan adalah analisis isi kualitatif yang diawali dengan analisis berbagai data yang berhasil dikumpulkan peneliti.

Dalam mengumpulkan data, peneliti menetapkan parameter data penelitian. Mengingat objek penelitian ini adalah Strategi PT HM Sampoerna Tbk Terhadap 'Karyawan Pabrik Surabaya Positif COVID-19', data yang diambil adalah data yang berhubungan dengan konteks tersebut. Dalam hal ini, tiga rilis pers yang dipublikasikan di website resmi PT HM Sampoerna. Dari data yang terkumpul, peneliti akan mendeskripsikan strategi image repair yang dijalankan PT HM Sampoerna Tbk dalam memperbaiki citra positif perusahaan.

Strategi penelitian menggunakan studi kasus yang mengkaji secara rinci atas suatu latar, subjek, atau peristiwa tertentu (Mulyana, 2003, hal 201). Sementara untuk menguji keabsahan data yang ada, penelitian ini memakai teknik teori triangulasi, yakni membandingkan data yang diperoleh dengan teori yang ada untuk memperkuat argumentasi penelitian. Triangulasi teori dilakukan dengan menguraikan pola, hubungan dan menyertakan penjelasan yang muncul dari analisis (Bungin, 2011).

Setelah pemilihan data selesai dilakukan, peneliti melakukan analisis data, dan penarikan kesimpulan. Analisis data terdiri atas pengujian, pengkategorian, maupun pengkombinasian kembali bukti-bukti untuk merujuk 
kepada proposisi awal sebuah penelitian (Yin, 2008).

\section{ANALISIS DAN PEMBAHASAN Profil Data}

Telah dijelaskan dalam bab sebelumnya, penelitian ini merupakan studi kasus PT HM Sampoerna Tbk terhadap 'Karyawan Pabrik Surabaya Positif COVID-19' dan mengambil data penelitian 3 (tiga) rilis pers yang dipublikasikan di kanal Pusat Informasi Media, yang menjadi bagian dari website resmi perusahaan www.pmi.com (Philip Morris Indonesia). Merujuk pada keterangan website, PT Philip Morris Indonesia (PT PMI) merupakan afiliasi Philip Morris International di Indonesia. Pada bulan Mei 2005, PT Philip Morris Indonesia mengakuisisi mayoritas saham dari PT HM Sampoerna.Tbk (Sampoerna).
Saat ini, PT Philip Morris Indonesia mempunyai $92.50 \%$ dari saham Sampoerna.

Ketiga rilis pers yang menjadi data penelitian adalah sebagai berikut.

1. Komitmen dan Upaya Sampoerna Dalam Mencegah Penyebaran COVID-19 di Seluruh Area Kantor dan Fasilitas Produksi. Dipublikasikan pada 1 Mei 2020 (Philip Morris Indonesia, 2020).

2. Komitmen Sampoerna Pada Kualitas Produk dan Integritas Merek. Dipublikasikan pada 2 Mei 2020 (Philip Morris Indonesia, 2020).

Mendukung Perpanjangan PSBB Surabaya Raya, Sampoerna Hentikan Kegiatan Produksi Selama 3 Minggu Kedepan. Dipublikasikan pada 11 Mei 2020 (Philip Morris Indonesia, 2020).

Tabel 1. Hasil Analisis Rilis Pers 1: Komitmen dan Upaya Sampoerna dalam Mencegah Penyebaran COVID-19 di Seluruh Area Kantor dan Fasilitas Produksi

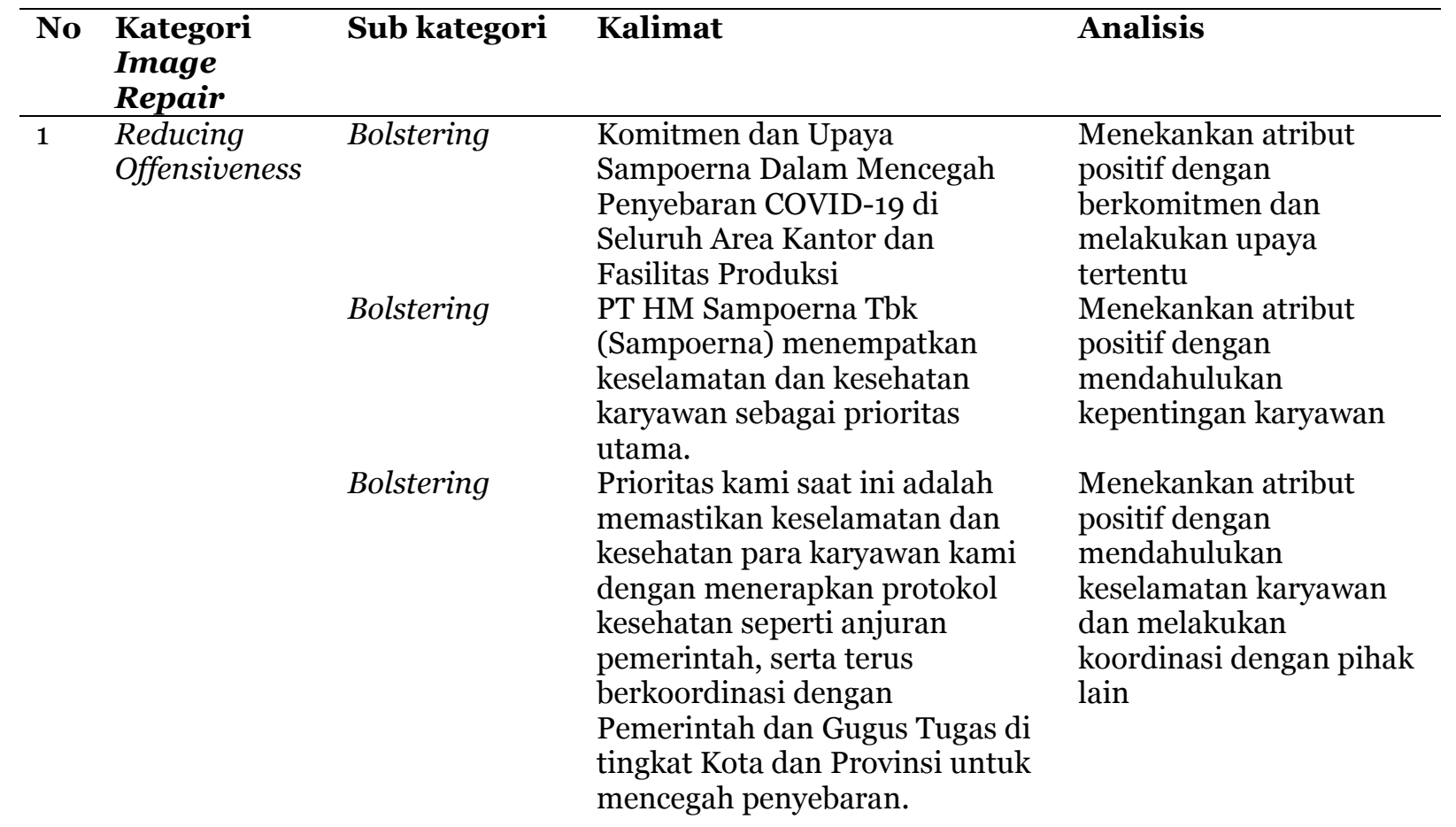




\begin{tabular}{|c|c|c|c|c|}
\hline No & $\begin{array}{l}\text { Kategori } \\
\text { Image } \\
\text { Repair }\end{array}$ & Sub kategori & Kalimat & Analisis \\
\hline 2 & $\begin{array}{l}\text { Corrective } \\
\text { Action }\end{array}$ & Compensation & 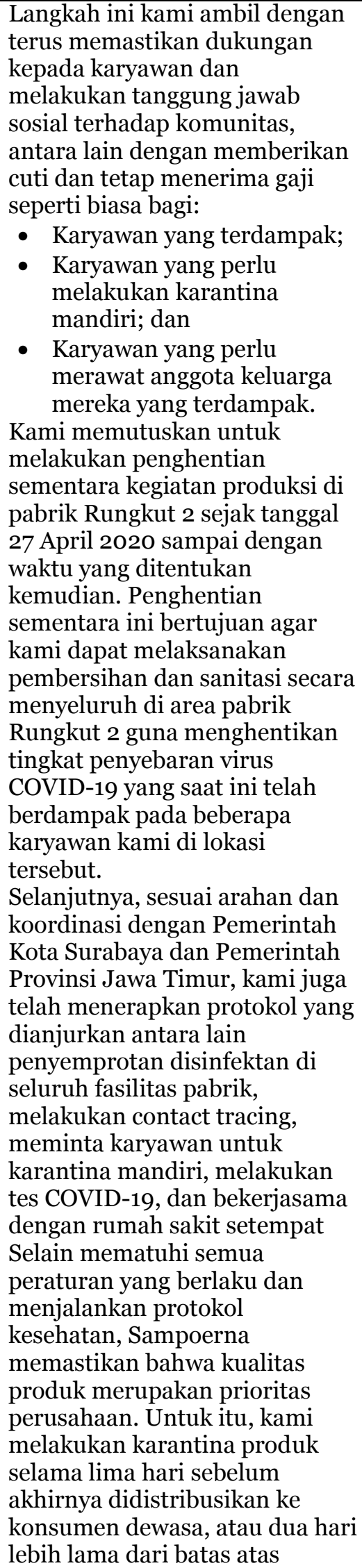 & $\begin{array}{l}\text { Mencoba memulihkan } \\
\text { situasi dengan } \\
\text { memastikan kualitas } \\
\text { produk tetap terjaga dan } \\
\text { telah melewati saran, } \\
\text { bahkan di atas saran dari } \\
\text { European CDC dan } \\
\text { WHO }\end{array}$ \\
\hline
\end{tabular}




\begin{tabular}{|c|c|c|c|c|}
\hline No & $\begin{array}{l}\text { Kategori } \\
\text { Image } \\
\text { Repair }\end{array}$ & Sub kategori & Kalimat & Analisis \\
\hline 3 & $\begin{array}{l}\text { Evading } \\
\text { Responsibility }\end{array}$ & $\begin{array}{l}\text { Good } \\
\text { Intentions }\end{array}$ & $\begin{array}{l}\text { stabilitas lingkungan COVID-19 } \\
\text { yang disarankan oleh European } \\
\text { CDC (European Centre for } \\
\text { Disease Prevention and Control) } \\
\text { dan juga World Health } \\
\text { Organization (WHO) yang } \\
\text { mengatakan bahwa COVID-19 } \\
\text { dapat bertahan selama 72 jam } \\
\text { pada permukaan plastik dan } \\
\text { stainless steel, kurang dari } 4 \text { jam } \\
\text { pada tembaga dan kurang dari } \\
\text { 24 jam pada kardus. } \\
\text { Sejak Pemerintah melakukan } \\
\text { upaya pencegahan penyebaran } \\
\text { COVID-19 di pertengahan bulan } \\
\text { Maret 2020, Sampoerna juga } \\
\text { telah melakukan berbagai upaya } \\
\text { dan menerapkan praktik } \\
\text { protokol kesehatan secara ketat } \\
\text { di seluruh area kantor dan } \\
\text { fasilitas produksi untuk } \\
\text { melindungi karyawan kami }\end{array}$ & $\begin{array}{l}\text { Mengurangi tanggung } \\
\text { jawab dengan } \\
\text { menyatakan sejak Maret, } \\
\text { yaitu dua bulan sebelum } \\
\text { peristiwa karyawan } \\
\text { positif COVID-19, } \\
\text { Sampoerna sudah } \\
\text { memiliki niat baik dalam } \\
\text { menerapkan protokol } \\
\text { kesehatan }\end{array}$ \\
\hline
\end{tabular}

Rilis pers 1 ini memiliki isi terpanjang dibandingkan kedua rilis pers lainnya. Dirilis ini, pihak PT HM Sampoerna Tbk memberikan keterangan yang cukup rinci mengenai langkahlangkah preventif yang telah dilakukannya. Terdapat temuan penggunaan kategori Reducing Offensiveness dengan sub kategori Bolstering seperti "PT HM Sampoerna Tbk (Sampoerna) menempatkan keselamatan dan kesehatan karyawan sebagai prioritas utama". Bolstering seperti yang diungkapkan W. L Benoit (1995) mengacu pada membahas tindakan yang dilakukan pihak tertuduh sebagai sarana untuk mengimbangi tindakan ofensif atau peristiwa yang terjadi. Pihak tertuduh dalam hal ini PT Sampoerna Tbk berusaha memberi impresi kepada publik bahwa perusahaan fokus dalam memprioritaskan kesehatan karyawan di tengah peristiwa yang terjadi.

Alasan penggunaan strategi ini semakin kuat jika melihat hasil penelitian dari Haigh \& Brubaker (2010) yang menyatakan, Reducing Offensiveness dapat meningkatkan persepsi organization-public relationship (OPR), sebuah pengelolaan hubungan antara organisasi dan publik.

Terdapat pula kategori Corrective Action seperti pada kalimat berikut.

"Selanjutnya, sesuai arahan dan koordinasi dengan Pemerintah Kota Surabaya dan Pemerintah Provinsi Jawa Timur, kami juga telah menerapkan protokol yang dianjurkan antara lain penyemprotan disinfektan di seluruh fasilitas pabrik, melakukan contact tracing, meminta karyawan untuk karantina mandiri, melakukan tes COVID-19, dan bekerjasama dengan rumah sakit setempat”

Hal ini sesuai dengan definisi Corrective Action oleh W. L Benoit (1995) bahwa tertuduh mencoba memulihkan situasi dengan melakukan berbagai tindakan reaktif.

Penemuan terakhir adalah kategori Evading Responsibility dengan sub 
kategori Good Intentions. Ini dapat dilihat pada kutipan berikut.

"Sejak Pemerintah melakukan upaya pencegahan penyebaran COVID-19 di pertengahan bulan Maret 2020, Sampoerna juga telah melakukan berbagai upaya dan menerapkan praktik protokol kesehatan secara ketat di seluruh area kantor dan fasilitas produksi untuk melindungi karyawan kami”.
Tertuduh seolah ingin memperlihatkan bahwa telah ada niat baik dan antisipasi, sehingga kadar kesalahan tidak sepenuhnya dapat dibebankan kepada tertuduh. Ini sesuai dengan yang dikatakan W. L Benoit (1995) bahwa Good Intentions bertujuan mengurangi kadar kesalahan yang dituduhkan kepada tertuduh.

Tabel 2. Hasil Analisis Rilis Pers 2: Komitmen Sampoerna Pada Kualitas Produk dan Integritas Merek

\begin{tabular}{|c|c|c|c|c|}
\hline No & $\begin{array}{l}\text { Kategori } \\
\text { Image } \\
\text { Repair }\end{array}$ & Sub kategori & Kalimat & Analisis \\
\hline \multirow[t]{3}{*}{1} & $\begin{array}{l}\text { Reducing } \\
\text { Offensiveness }\end{array}$ & Bolstering & $\begin{array}{l}\text { Komitmen Sampoerna Pada } \\
\text { Kualitas Produk dan Integritas } \\
\text { Merek }\end{array}$ & $\begin{array}{l}\text { Menekankan atribut } \\
\text { positif dengan } \\
\text { melakukan komitmen }\end{array}$ \\
\hline & & Bolstering & $\begin{array}{l}\text { Sampoerna berkomitmen untuk } \\
\text { selalu memastikan kualitas } \\
\text { tertinggi dan integritas merek } \\
\text { atas produk-produk kami pada } \\
\text { konsumen dewasa. }\end{array}$ & $\begin{array}{l}\text { Menekankan atribut } \\
\text { positif dengan } \\
\text { melakukan komitmen }\end{array}$ \\
\hline & & Differentiation & $\begin{array}{l}\text { Selain itu, penting bagi para } \\
\text { konsumen dewasa kami untuk } \\
\text { mengikuti anjuran Pemerintah, } \\
\text { seperti menjalankan praktik } \\
\text { kebersihan umum antara lain } \\
\text { mencuci tangan, menutup mulut } \\
\text { saat batuk/bersin, menjaga jarak } \\
\text { sosial/fisik, dll. }\end{array}$ & $\begin{array}{l}\text { Menempatkan perilaku } \\
\text { konsumen dewasa } \\
\text { sebagai syarat, agar } \\
\text { tindakan dan upaya yang } \\
\text { dilakukan Sampoerna } \\
\text { menjadi berarti }\end{array}$ \\
\hline \multirow[t]{2}{*}{2} & $\begin{array}{l}\text { Corrective } \\
\text { Action }\end{array}$ & & $\begin{array}{l}\text { Untuk itu, kami telah } \\
\text { mengambil langkah-langkah } \\
\text { penting dalam memastikan } \\
\text { produk kami tidak terpapar } \\
\text { COVID-19. Di awal tahun dan } \\
\text { selama masa pandemi COVID- } \\
\text { 19, kami telah meningkatkan } \\
\text { penerapan protokol kesehatan } \\
\text { dan sanitasi di seluruh fasilitas } \\
\text { pabrik, gudang, serta rantai } \\
\text { pasokan kami. }\end{array}$ & $\begin{array}{l}\text { Mencoba memulihkan } \\
\text { situasi dengan } \\
\text { menerapkan protokol } \\
\text { kesehatan dan sanitasi }\end{array}$ \\
\hline & & & $\begin{array}{l}\text { Berpedoman pada anjuran dan } \\
\text { peraturan Pemerintah, kami } \\
\text { telah menerapkan protokol } \\
\text { kesehatan dan sanitasi } \\
\text { tambahan sebagai berikut sejak } \\
\text { bulan Maret: } \\
\text { - Menyediakan dan } \\
\text { memastikan penggunaan } \\
\text { perlengkapan perlindungan } \\
\text { diri seperti masker dan } \\
\text { hand-sanitizer; }\end{array}$ & $\begin{array}{l}\text { Mencoba memulihkan } \\
\text { situasi dengan } \\
\text { menerapkan protokol } \\
\text { kesehatan dan sanitasi }\end{array}$ \\
\hline
\end{tabular}




\begin{tabular}{|c|c|c|c|c|}
\hline No & $\begin{array}{l}\text { Kategori } \\
\text { Image } \\
\text { Repair }\end{array}$ & Sub kategori & Kalimat & Analisis \\
\hline & & & $\begin{array}{l}\text { Membatasi akses ke fasilitas } \\
\text { produksi hanya kepada } \\
\text { karyawan yang } \\
\text { berkepentingan; } \\
\text { - Melakukan karantina } \\
\text { produk selama } 5 \text { (lima) hari } \\
\text { sebelum pendistribusian, } \\
\text { yaitu jangka waktu } \\
\text { karantina yang lebih lama } \\
\text { dari anjuran Organisasi } \\
\text { Kesehatan Dunia (WHO) } \\
\text { dan European CDC } \\
\text { (European Centre for } \\
\text { Disease Prevention and } \\
\text { Control) }\end{array}$ & \\
\hline
\end{tabular}

Isi rilis kedua lebih banyak mengambil perspektif dari langkah yang telah diambil perusahaan dalam menjamin kualitas produk, yang penting dalam kaitan keberlanjutan bisnis yang dijalankan HM Sampoerna Tbk. Temuan kategori Reducing Offensiveness dan Corrective Action pada rilis ini kembali berjumlah hampir berimbang (lihat tabel 4). Ada satu sub kategori dari Reducing Offensiveness, yaitu Differentiation yang tidak ditemukan dalam rilis pertama. Ini dapat dilihat pada kutipan berikut.

"Selain itu, penting bagi para konsumen dewasa kami untuk mengikuti anjuran Pemerintah, seperti menjalankan praktik kebersihan umum antara lain mencuci tangan, menutup mulut saat batuk/bersin, menjaga jarak sosial/fisik, dll”.
Differentiation digunakan untuk menempatkan tindakan atau peristiwa tersebut dalam konteks dengan tindakan/peristiwa lain yang lebih ofensif (yang mungkin dilakukan oleh orang lain) dan digunakan untuk berpendapat bahwa jika diperbandingkan, maka tindakan/peristiwa yang terjadi tidak berarti (W. L Benoit, 1995). Dengan menekankan perilaku konsumen dewasa sebagai syarat, agar komitmen yang dilakukan Sampoerna selalu memastikan kualitas tertinggi pada produknya tidak sia-sia. Disamping itu, ditemukan juga kategori Corrective Action pada rilis ini, namun kategori Evading Responsibility yang ditemukan dalam rilis sebelumnya, tidak ditemukan lagi 
Tabel 3. Hasil Analisis Rilis Pers 3: Mendukung Perpanjangan PSBB Surabaya Raya, Sampoerna Hentikan Kegiatan Produksi Selama 3 Minggu Kedepan

\begin{tabular}{|c|c|c|c|c|}
\hline No & $\begin{array}{l}\text { Kategori } \\
\text { Image } \\
\text { Repair }\end{array}$ & Sub kategori & Kalimat & Analisis \\
\hline 1 & Denial & $\begin{array}{l}\text { Shifting the } \\
\text { Blame }\end{array}$ & $\begin{array}{l}\text { Memberikan semangat positif, } \\
\text { motivasi dan edukasi bagi } \\
\text { seluruh karyawan agar mereka } \\
\text { patuh menerapkan protokol } \\
\text { kesehatan dan gaya hidup sehat } \\
\text { sesuai anjuran Pemerintah. }\end{array}$ & $\begin{array}{l}\text { Kalimat “Memberikan } \\
\text { edukasi dan karyawan } \\
\text { agar patuh", seolah, } \\
\text { menyalahkan perilaku } \\
\text { korban sehingga terkena } \\
\text { COVID-19 }\end{array}$ \\
\hline 2 & $\begin{array}{l}\text { Evading } \\
\text { Responsibility }\end{array}$ & Provocation & $\begin{array}{l}\text { "Dua fokus utama Sampoerna } \\
\text { saat ini adalah memberikan } \\
\text { upaya dan dukungan terbaik } \\
\text { bagi para karyawan yang } \\
\text { terdampak COVID-19 agar } \\
\text { mereka mendapatkan perawatan } \\
\text { medis yang tepat dan dapat } \\
\text { segera sehat. }\end{array}$ & $\begin{array}{l}\text { Sampoerna menyatakan } \\
\text { upaya yang mereka } \\
\text { lakukan merupakan } \\
\text { respons atas karyawan } \\
\text { yang sudah terdampak } \\
\text { COVID-19 sehingga } \\
\text { usaha respons itu } \\
\text { menjadi masuk akal }\end{array}$ \\
\hline \multirow[t]{4}{*}{3} & \multirow[t]{4}{*}{$\begin{array}{l}\text { Reducing } \\
\text { Offensiveness }\end{array}$} & Bolstering & $\begin{array}{l}\text { Keputusan ini telah } \\
\text { dikoordinasikan dengan } \\
\text { Pemerintah dan Gugus Tugas } \\
\text { Kota Surabaya dan Provinsi } \\
\text { Jawa Timur dengan } \\
\text { pertimbangan menyeluruh } \\
\text { untuk mendukung keberhasilan } \\
\text { pelaksanaan Perpanjangan PSBB } \\
\text { Surabaya Raya dalam } \\
\text { mengendalikan dan } \\
\text { menghentikan penyebaran } \\
\text { COVID-19 di Surabaya }\end{array}$ & $\begin{array}{l}\text { Menekankan atribut } \\
\text { positif dalam tindakan } \\
\text { dengan sudah } \\
\text { berkoordinasi dengan } \\
\text { pemerintah dan pihak } \\
\text { lain yang terkait }\end{array}$ \\
\hline & & Bolstering & $\begin{array}{l}\text { Direktur Sampoerna, Elvira } \\
\text { Lianita menyampaikan } \\
\text { apresiasinya atas dukungan } \\
\text { kepada Sampoerna, "Kami } \\
\text { mengucapkan terima kasih } \\
\text { kepada semua pihak, khususnya } \\
\text { pemerintah dan Gugus Tugas, } \\
\text { yang selalu mendukung, } \\
\text { membantu dan bergotong } \\
\text { royong untuk menekan dan } \\
\text { mencegah penyebaran COVID- } \\
\text { 19. }\end{array}$ & $\begin{array}{l}\text { Menekankan atribut } \\
\text { positif dengan } \\
\text { mengapresiasi usaha } \\
\text { pemerintah dan pihak } \\
\text { terkait }\end{array}$ \\
\hline & & Bolstering & $\begin{array}{l}\text { Keputusan kami untuk } \\
\text { menghentikan kegiatan produksi } \\
\text { selama tiga minggu ini adalah } \\
\text { bentuk dukungan kami untuk } \\
\text { ikut memutus tali penyebaran } \\
\text { COVID-19 di Surabaya. }\end{array}$ & $\begin{array}{l}\text { Menekankan atribut } \\
\text { positif dengan ikut } \\
\text { berpartisipasi dalam } \\
\text { menghentikan } \\
\text { penyebaran COVID-19 }\end{array}$ \\
\hline & & Bolstering & $\begin{array}{l}\text { Tidak sampai disitu, Sampoerna } \\
\text { berkomitmen untuk selalu } \\
\text { memastikan kualitas tertinggi } \\
\text { dan integritas merek atas } \\
\text { produk-produk Sampoerna yang } \\
\text { dihasilkan untuk konsumen } \\
\text { dewasa melalui penerapan } \\
\text { protokol kesehatan ketat yang } \\
\text { tentunya dibarengi dengan } \\
\text { penerapan Cara Berproduksi }\end{array}$ & $\begin{array}{l}\text { Menekankan atribut } \\
\text { positif dengan selalu } \\
\text { berkomitmen, } \\
\text { memastikan kualitas, } \\
\text { sudah mendapat izin } \\
\text { operasional, dan telah } \\
\text { melapor pelaksanaan } \\
\text { kegiatan industrinya }\end{array}$ \\
\hline
\end{tabular}




\begin{tabular}{l|l|l|l|l}
\hline No & $\begin{array}{l}\text { Kategori } \\
\text { Image } \\
\text { Repair }\end{array}$ & Sub kategori & Kalimat & Analisis \\
\hline \multicolumn{2}{c}{$\begin{array}{l}\text { yang Baik (Good Manufacturing } \\
\text { Practices). }\end{array}$}
\end{tabular}

Seluruh fasilitas produksi

Sampoerna tersebut telah mendapatkan izin operasional dan mobilitas kegiatan industri (IOMKI) dan secara berkala, Sampoerna juga melaporkan pelaksanaan kegiatan industri kepada Kementerian

Perindustrian RI.

Minimization Dengan penghentian sementara kegiatan produksi di 2 (dua) fasilitas pabrik di Surabaya, Sampoerna tetap menjamin ketersediaan pasokan produknya. Saat ini, 4 (empat) fasilitas produksi Sampoerna lainnya masih beroperasi.

Compensation

Compensation

Dengan keputusan ini, maka akan memberikan waktu bagi seluruh karyawan Sampoerna yang berlokasi di Surabaya untuk tetap di rumah selama masa perpanjangan PSBB berlangsung yang juga bertepatan dengan masa Idul Fitri. Meskipun karyawan Sampoerna di Surabaya tidak melakukan kegiatan produksi, mereka tetap menerima gaji secara penuh, termasuk menerima Tunjangan Hari Raya. Elvira juga menjelaskan, selain menjaga kesehatan dan keselamatan karyawan, Sampoerna juga berkomitmen untuk menjamin stabilitas ekonomi karyawannya. Elvira menyampaikan komitmen Sampoerna untuk tidak melakukan pemutusan hubungan kerja (PHK) selama masa pandemi ini dan memberikan gaji secara penuh, termasuk menerima Tunjangan Hari Raya

Transcendence "Komitmen Sampoerna terkait penerapan protokol kesehatan yang ketat, serta jaminan stabilitas pekerjaan dan penghasilan karyawan ini sejalan dengan imbauan Pemerintah agar semua pihak bergotong
Dengan menekankan dari 6 (enam) pabrik, hanya dua yang tutup, maka penutupan pabrik tidak terlalu berpengaruh pada operasional perusahaan karena masih memiliki banyak pabrik yang tetap beroperasi

Sampoerna memberikan kompensasi cuti dan tetap menerima gaji kepada karyawan yang menjadi korban

Kedua kalinya dalam rilis pers ini menyinggung kompensasi yang diberikan kepada karyawan

Bahwa seluruh tindakan yang diambil untuk kepentingan yang lebih luas, yaitu bangsa dan negara Indonesia. 


\begin{tabular}{|c|c|c|c|c|}
\hline No & $\begin{array}{l}\text { Kategori } \\
\text { Image } \\
\text { Repair }\end{array}$ & Sub kategori & Kalimat & Analisis \\
\hline 2 & $\begin{array}{l}\text { Corrective } \\
\text { Action }\end{array}$ & Transcendence & $\begin{array}{l}\text { royong, saling membantu dan } \\
\text { melakukan upaya terbaik agar } \\
\text { Indonesia segera keluar dari } \\
\text { situasi pandemi COVID-19 } \\
\text { dengan tetap menjaga stabilitas } \\
\text { sosial ekonomi,” } \\
\text { Sampoerna menegaskan } \\
\text { komitmennya untuk terus } \\
\text { berpartisipasi aktif dan } \\
\text { memberikan upaya terbaik bagi } \\
\text { karyawan, mitra usaha, } \\
\text { konsumen dewasa, serta } \\
\text { masyarakat luas sebagai wujud } \\
\text { sumbangsih perusahaan untuk } \\
\text { ikut menjaga Indonesia. } \\
\text { Mendukung Perpanjangan PSBB } \\
\text { Surabaya Raya, Sampoerna } \\
\text { Hentikan Kegiatan Produksi } \\
\text { Selama } 3 \text { Minggu Kedepan } \\
\text { PT HM Sampoerna Tbk. } \\
\text { (Sampoerna) memutuskan } \\
\text { untuk menghentikan sementara } \\
\text { kegiatan produksi di } 2 \text { (dua) } \\
\text { pabriknya yang berlokasi di } \\
\text { Surabaya, yaitu Rungkut } 1 \text { dan } \\
\text { Rungkut } 2 \text { sampai dengan } 1 \\
\text { Juni. Kegiatan produksi akan } \\
\text { dimulai kembali pada tanggal } 2 \\
\text { Juni 2020. }\end{array}$ & $\begin{array}{l}\text { Mencoba memulihkan } \\
\text { situasi dengan } \\
\text { melakukan upaya } \\
\text { menutup kegiatan } \\
\text { produksi } \\
\text { Mencoba memulihkan } \\
\text { situasi dengan } \\
\text { melakukan upaya } \\
\text { menutup kegiatan } \\
\text { produksi }\end{array}$ \\
\hline
\end{tabular}

Rilis pers ketiga mengambil perspektif berbeda, yaitu usaha kooperatif PT Sampoerna Tbk dengan pihak otoritas Surabaya untuk menanggulangi penularan virus secara lebih lanjut. Kali ini temuan kategori Reducing Offensiveness mendominasi rilis. Dari enam sub kategori Reducing Offensiveness, ditemukan empat sub kategori dengan dua diantaranya merupakan penggunaan sub kategori baru yang tidak ditemukan baik dirilis pertama maupun kedua. Dua sub kategori baru itu adalah Minimization dan Transcendence

Sub kategori Minimization misalnya, ditemukan dalam kalimat berikut.

Dengan penghentian sementara kegiatan produksi di 2 (dua) fasilitas pabrik di Surabaya,
Sampoerna tetap menjamin ketersediaan pasokan produknya. Saat ini, 4 (empat) fasilitas produksi Sampoerna lainnya masih beroperasi”.

Penggunaan

Minimization menunjukkan bahwa konsekuensi atau keparahan atas tindakan terhadap peristiwa itu dilebih-lebihkan. Dengan menyebutkan dari 6 (enam) pabrik, hanya dua yang tutup, maka penutupan pabrik lainnya akibat karyawan yang terkena COVID-19 tidak terlalu berpengaruh pada operasional perusahaan karena PT Sampoerna Tbk masih memiliki banyak pabrik yang tetap beroperasi seperti biasa. Untuk sub kategori Transcendence, terlihat pada kalimat berikut. 
“Komitmen Sampoerna terkait penerapan protokol kesehatan yang ketat, serta jaminan stabilitas pekerjaan dan penghasilan karyawan ini sejalan dengan imbauan Pemerintah agar semua pihak bergotong-royong, saling membantu dan melakukan upaya terbaik agar Indonesia segera keluar dari situasi pandemi COVID-19 dengan tetap menjaga stabilitas sosial ekonomi”.

Transcendence menurut W. L Benoit (1995) berusaha menempatkan tindakan/peristiwa dalam konteks yang lebih luas, misalnya moral, sehingga pada akhirnya membenarkan tindakan atau peristiwa tersebut. Dengan menyatakan bahwa komitmen yang telah dilakukan PT Sampoerna sebagai bagian dari gotongroyong agar Indonesia dapat segera keluar dari pandemi, maka tindakan yang diambil PT Sampoerna Tbk untuk kepentingan nasional yang lebih luas.
Dibandingkan dua rilis sebelumnya, rilis ketiga ini cukup banyak memakai berbagai kategori lain, yaitu Evading Responsibility, dan satu kategori Denial yang tidak ditemukan di dua rilis sebelumnya (lihat tabel 4). Penggunaan kedua kategori ini terlihat kurang tepat karena menurut Benoit dan Hirson (2001) strategi ini seolah tertuduh menghindari mengambil tanggung jawab untuk itu. Ini tentu tidak konsisten dengan berbagai penggunaan kategori sebelumnya, yang telah memperlihatkan berbagai komitmen yang telah dilakukan PT Sampoerna Tbk, namun di sisi lain secara tidak langsung menyalahkan karyawan karena lalai mematuhi protokol kesehatan. Ini terlihat pada penggunaan kategori Denial dengan sub kategori Shifting The Blame lewat kalimat, "Edukasi bagi seluruh karyawan agar mereka patuh menerapkan protokol kesehatan dan gaya hidup sehat sesuai anjuran Pemerintah”.

Tabel 4. Frekuensi Penggunaan Strategi Image Repair di Seluruh Rilis Pers

\begin{tabular}{l|l|l|l|l|l}
\hline No & Kategori Image Repair & Rilis Pers 1 & $\begin{array}{l}\text { Rilis Pers } \\
\mathbf{2}\end{array}$ & $\begin{array}{l}\text { Rilis Pers } \\
\mathbf{3}\end{array}$ & Total \\
\hline $\mathbf{1}$ & Denial & - & - & 1 & $\mathbf{1}$ \\
$\mathbf{2}$ & Evading Responsibility & 1 & - & 1 & $\mathbf{2}$ \\
$\mathbf{3}$ & Reducing Offensiveness & 4 & 3 & 10 & $\mathbf{1 7}$ \\
$\mathbf{4}$ & Corrective Action & 3 & 2 & 2 & 7 \\
$\mathbf{5}$ & Mortification & - & - & - & - \\
\hline
\end{tabular}

Dari keseluruhan paparan penelitian ini, dapat dilihat bahwa setiap rilis mengandung strategi yang berbeda (tabel 4). Namun, secara keseluruhan, Reducing Offensiveness menjadi yang paling dominan digunakan oleh PT HM Sampoerna. Ini menunjukkan bahwa perusahaan merasa terus-menerus diserang, dan karena itu serangan harus diredam. Oleh karena itu, baik pada rilis 1,2, ataupun 3, strategi Reducing Offensiveness secara konsisten dan bahkan yang paling konsisten digunakan untuk meredam persepsi negatif publik sehingga image repair diharapkan tercapai dengan baik.

Penggunaan strategi ini yang menurut Pang et al., (2012) masuk dalam kategori strategi jangka menengah (Bolstering, Transcendence, Minimization, Differentiation), harus dilakukan secara hati-hati karena dapat dilihat sebagai "penyesatan perhatian" (Chaffee \& Metzger, 2001), terutama ketika audience 
kritis terhadap organisasi. Selain itu, strategi ini bisa lebih persuasif ketika disampaikan oleh pihak ketiga yang netral daripada organisasi itu sendiri (Benoit \& Czerwinski, 1997), tapi dalam hal ini seluruh penyampaian strategi dilakukan oleh pihak PT HM Sampoerna Tbk sendiri.

Dari tabel 4, juga dapat simpulkan bahwa PT HM Sampoerna Tbk cukup jeli untuk tidak menggunakan kategori Mortification mengingat dampaknya yang cukup besar bagi organisasi. Benoit (1997) memperingatkan bahwa "Mortification berarti mengakui kesalahan, yang dapat membantu citra perusahaan tetapi dapat mengurangi kemampuan dalam kemungkinan memenangkan gugatan hukum

\section{KESIMPULAN}

Berdasarkan hasil penelitian dan analisis data pada tiga rilis pers yang diterbitkan PT HM Sampoerna Tbk, penggunaan strategi Image Repair untuk kategori Reducing Offensiveness dan Corrective Action relatif berimbang pada rilis pers 1 dan 2, tetapi penggunaan Reducing Offensiveness menjadi dominan pada rilis pers 3. Penggunaan kategori Evading Responsibility dan Denial sangat minim, sedangkan kategori Mortification sama sekali tidak digunakan.

Penggunaan kategori strategi Reducing Offensiveness relatif sudah tepat karena jika merujuk pada keterangan sebelumnya, strategi ini paling sering digunakan dalam jenis krisis kecelakaan dan/atau tantangan, termasuk situasi kerusakan produk. Dalam hal ini, sorotan atas keamanan kualitas rokok yang dihasilkan PT HM Sampoerna Tbk karena karyawannya terkena COVID-19. Pada semua rilis pers, PT HM Sampoerna Tbk menegaskan komitmennya untuk tetap menjaga kualitas produknya. Namun di sisi lain, penggunaan Reducing Offensiveness yang dominan dapat mendatangkan sisi negatif.

\section{DAFTAR PUSTAKA}

Belarminus, R. (2020). Pabrik Sampoerna Surabaya Ditutup Setelah 2 Karyawan Positif Covid19. Kompas.Com.

https://regional.kompas.com/read/2 020/04/30/11210601/pabriksampoerna-surabaya-ditutupsetelah-2-karyawan-positif-covid-19.

Benoit, W. L. (1995). Accounts, excuses, apologies: A theory of image restoration strategies. State University of New York Press.

Benoit, W. L. (1997), Hugh Grant's image restoration discourse: an actor apologizes. Communication Quarterly, Vol. 45, No. 3, pp. 251267.
Benoit, W. L. (2000). Another visit to the theory of image restoration strategies. Communication Quarterly, 48(1), 40-43. https://doi.org/10.1080/014633700 09385578

Benoit, W. L. (1997), Hugh Grant's image restoration discourse: an actor apologizes. Communication Quarterly, Vol. 45, No. 3, pp. 251267.

Benoit, W. L., \& Brinson, S. L. (1994). AT\&T: "Apologies are not enough." Communication Quarterly, 42(1), 7588. 
Benoit, W. L., \& Czerwinski, A. (1997). A critical analysis of USAir's image repair discourse. Business Communication Quarterly, Vol. 60, pp. 38-57.

Benoit, W. L., \& Hirson, D. (2001). Doonesbury versus the Tobacco Institute: the Smoke Starters' coupon. Communication Quarterly, Vol. 49, No. 3, pp. 279-294.

Benoit, W. L., \& Pang, A. (2008). Crisis communication and image repair discourse. In Tricia L. Hansen-Horn \& Bonita Dostal Neff (Eds.), Public Relations: From theory to practice (pp. 244-261). Boston, MA: Pearson.

Blaney, J. R., Benoit, W. L., \& Brazeal, L, M. (2002). Blowout!: Firestone's image restoration campaign. Public Relations Review, Vol. 28, pp. 379392.

Brinson, S.L., \& Benoit, W. L. (1999). The tarnished star: Restoring Texaco's damaged public image. Communication Quarterly, 12, 483510.

Bungin, B. (2011). Konstruksi Sosial Media Massa: Kekuatan Pengaruh Media Massa, Iklan Televisi, Dan Keputusan Konsumen Serta Kritik Terhadap Peter. L Berger \& Thomas Luckmann. Kencana.

Burke, K. (1970). Rhetoric of religion. Berkeley: University of California Press.

Caldiero, C. T., Taylor, M., \& Ungureanu, L. (2009). Image Repair Tactics and Information Subsidies During Fraud Crisis. Journal of Public Relations Research, Vol. 21, No. 2, pp. 218-228.

Chaffee, S. H., \& Metzger, M. J. (2001). The End of Mass Communication? Mass Communication and Society, 4(4), 365-379. https://doi.org/10.1207/S15327825 MCSO404_3
Choi, Y., \& Lin, Y. H. (2009). Consumer responses to Mattel products recalls posted on online bulletin boards: Exploring the two types of emotion. Journal of Public Relations Research, 21 (2), 198-207.

Coombs, W. T. (2007), Ongoing Crisis Communication, Sage, Thousand Oaks.

Coombs, W. T. (2008). Crisis communication. In Wolfgang Donsbach (Ed.) International Encyclopedia of Communication (pp. 1054-1060). Malden, MA: Blackwell.

Coombs, W. T., \& Schmidt, L. (2000). An empirical analysis of image restoration: Texaco's racism crisis. Journal of Public Relations Research, Vol. 12, No. 2, pp. 163-178.

Cowden, K., \& Sellnow, T. L. (2002). Issues advertising as crisis communication: Northwest Airlines' use of image restoration strategies during the 1998 pilot's strike. The Journal of Business Communication, Vol. 39, pp. 193-219.

Dardis, F., \& Haigh, M. M. (2009). Prescribing versus describing: testing image restoration strategies in acrisis situation. Corporate Communications: An International Journal, Vol. 14, No. 1, pp. 101-118.

Entman, R. M. (1993). Framing: Towards clarification of a fractured paradigm. Journal of Communication, Vol. 43, No. 4, pp. 51-58.

Friedman, R.A. (2001). Managing diversity and second-order conflict. Journal of Conflict Management. 12 (2): 132-153

Gilpin, D. R. (2008). Narrating the organizational self: Reframing the role of the news release. Public Relations Review, 34(1), 9-18. 
Haigh, M. M., \& Brubaker, P. (2010). Examining how image restoration strategy impacts perceptions of corporate social responsibility, organization public relationships, and source credibility. Corporate Communications: An International Journal, 15(4), 453-468. https://doi.org/10.1108/13563281011 085538

Haryanto. (2020). Pabrik Tutup, Secara Teknikal Begini Arah Saham HM Sampoerna. Cnbcindonesia.Com. https://www.cnbcindonesia.com/ma rket/20200504101318-17155979/pabrik-tutup-secarateknikal-begini-arah-saham-hmsampoerna.

Kim, S., Avergy, E. J., \& Lariscy, R. W. (2009). Are crisis communicator practicing what we preach?: An evaluation of crisis response strategy analyzed in public relations research from 1991 to 2009. Public Relations Review, 35(4), 446-448.

Mulyana, Deddy. (2003). Metodologi Penelitian Kualitatif. Remaja Rosdakarya, hal. 201.

Nijkrake, J., Gosselt, J. F., \& Gutteling, J. M. (2015). Competing frames and tone in corporate communication versus media coverage during a crisis. Public Relations Review, 41(1), 8088.

Pace, K. M., Fediuk, T. A., \& Botero, I. C. (2010). The acceptance of responsibility and expressions of regret in organizational apologies after a transgression. Corporate Communications: An International Journal, 15(4), 410-427.

Pang, A. (2006), Conflict positioning in crisis communication: Integrating Contingency stance with Image Repair strategies. University of Missouri.
Pang, A., Ho, B., \& Malik, N. (2012). Repairing an organization's image in times of crises: What strategies to use when? Conference on Corporate Communication, 485-506.

Philip Morris Indonesia. (2020). Sekilas Sampoerna. Www.Pmi.Com.

Ramadhan, A. (2019). Kronologi Blackout: Dari Mati Lampu, Jokowi Marah, hingga Janji PLN. . Diakses pada. Kompas. https://nasional.kompas.com/read/2 019/08/o6/o8454741/kronologiblackout-dari-mati-lampu-jokowimarah-hingga-janji-pln.

Reissová, A., Žambochová, M., \& Sláma, V. (2018). The role of mass media in crisis communication. Scientific Papers of the University of Pardubice, Series D: Faculty of Economics and Administration, 25(1), 189-199.

Riza, Irfan. (2019). Komunikasi Krisis dengan Media: Belajar dari Kasus PLN. Warta Ekonomi. https://www.wartaekonomi.co.id/rea d242957/komunikasi-krisis-denganmedia-belajar-dari-kasus-pln.

Situmorang, R. (2020). Soal Karyawan Kena Covid-19, HM Sampoerna (HMSP) Tegaskan Tak Ada Penarikan Produk. Bisnis.Com. https://market.bisnis.com/read/202 00511/192/1238670/soal-karyawankena-covid-19-hm-sampoerna-hmsptegaskan-tak-ada-penarikan-produk

Wicaksono, P. (2020). Cek Fakta: Jutaan Rokok Sampoerna Terpapar COVID19 Beredar di Masyarakat? Ini Faktanya. Liputan6.Com. https://www.liputan6.com/cekfakta/read/4241659/cek-faktajutaan-rokok-sampoerna-terpaparcovid-19-beredar-di-masyarakat-inifaktanya.

Yin, R.K. (2008). Case Study Research: Design and Methods. 4th Edition, Sage Publications, Thousand Oaks. 